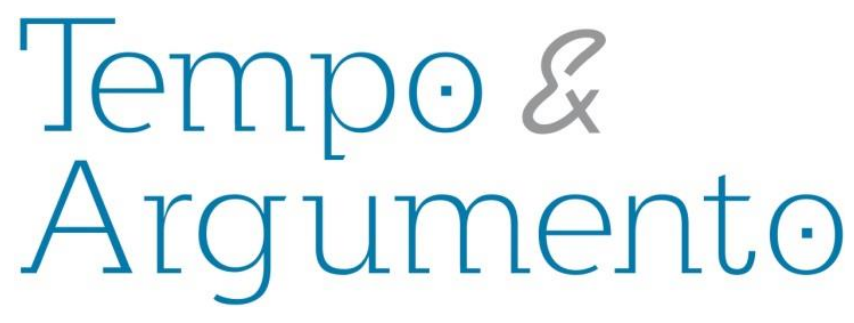

\title{
"Libres o muertos, jamás esclavos". Marxismo, peronismo y lucha armada: las Fuerzas Armadas Revolucionarias en la Argentina de los primeros setenta
}

\begin{abstract}
Resumen
Desde 1955 hasta la última dictadura militar, Argentina atravesó un período de creciente conflictividad social y política. Las organizaciones armadas fueron actores destacados en este proceso. Entre ellas, las Fuerzas Armadas Revolucionarias (FAR) condensan dos problemáticas clave del período: la identificación con el peronismo de vastos sectores de izquierda y la reivindicación de la violencia como forma de intervención política. Este artículo reconstruye los orígenes y la historia de las FAR entre 1960 y 1973, considerando 2 ejes analíticos: 1) el proceso de identificación de las FAR con el peronismo desde una perspectiva marxista y un proyecto socialista; y 2) su dinámica de funcionamiento como organización político-militar. En relación con ellos, se fundamentan 3 hipótesis. 1) Que los fundadores de las FAR atravesaron un proceso de doble ruptura (política e ideológica) respecto de sus partidos políticos de origen. 2) Que, sin embargo, las nuevas posturas conservaron ciertas huellas de origen que le imprimieron a las FAR su perfil distintivo. Y 3) que hacia 1972 tal perfil experimentó sustantivas variaciones que explican su acercamiento a Montoneros. Este artículo está basado en una estrategia metodológica cualitativa y se sustenta en fuentes documentales escritas y en entrevistas a ex-miembros de la organización.
\end{abstract}

Palabras clave: Nueva izquierda. Peronismo. Marxismo.

Violencia Política. Lucha Armada.

\section{Para citar este artículo:}

GONZÁLEZ CANOSA, Mora. “Libres o muertos, jamás esclavos". Marxismo, peronismo y lucha armada: las Fuerzas Armadas Revolucionarias en la Argentina de los primeros 1970. Tempo e Argumento, Florianópolis, v. 9, n. 22, p. 364 - 395, set./dez. 2017.

DOI: $10.5965 / 2175180309222017364$
http://dx.doi.org/10.5965/2175180309222017364 
"Free or dead, never slaves." Marxism, Peronism, and armed struggle: the Revolutionary Armed Forces in Argentina in the early 1970 s

\begin{abstract}
From 1955 until the last military dictatorship, Argentina went through a period of increasing social and political conflict. Armed organizations were prominent actors in this process. Among them, the Argentine Revolutionary Armed Forces (FAR) condense two key issues in the period: identification with Peronism in vast sectors of the left-wing and vindication of violence as a means of political intervention. This article reconstructs the origins and history of the FAR between 1960 and 1973, considering 2 analytical axes: 1) the process of identifying the FAR with Peronism from a Marxist perspective and a socialist project; and 2) its functioning dynamics as a political-military organization. Regarding them, 3 hypotheses are grounded. 1) That founders of the FAR went through a process of double break (political and ideological) concerning their political parties of origin. 2) That, nevertheless, the new positions preserved certain traces of origin that provided the FAR with its distinctive profile. And 3) that by 1972 such a profile underwent major variations that explain its closeness to Montoneros. This article is based on a qualitative methodological strategy and it is grounded in written documentary sources and interviews with former organization members.
\end{abstract}

Keywords: New left-wing. Peronism. Marxism. Political Violence. Armed Struggle.

\section{"Livres ou mortos, jamais escravos". Marxismo, peronismo e luta armada: as Forças Armadas Revolucionárias na Argentina no início dos anos 1970}

\section{Resumo}

Desde 1955 até a última ditadura militar, a Argentina passou por um período de crescente conflito social e político. As organizações armadas foram atores proeminentes nesse processo. Entre elas, as Forças Armadas Revolucionárias (FAR) condensam duas questões-chave no período: a identificação com o peronismo de vastos setores da esquerda e a reivindicação da violência como meio de intervenção política. Este artigo reconstrói as origens e a história das FAR entre 1960 e 1973, considerando 2 eixos analíticos: 1) o processo de identificação das FAR com o peronismo sob uma perspectiva marxista e um projeto socialista; e 2) sua dinâmica de funcionamento como organização político-militar. Em relação a eles, 3 hipóteses são fundamentadas. 1) Que os fundadores das FAR passaram por um processo de dupla ruptura (política e ideológica) em relação aos seus partidos políticos de origem. 2) Que, no entanto, as novas posturas preservaram certos vestígios de origem que proporcionaram às FAR seu perfil distintivo. E 3) Que, em 1972, tal perfil sofreu grandes variações que explicam sua aproximação com Montoneros. Este artigo baseia-se em uma estratégia metodológica qualitativa e fundamenta-se em fontes documentais escritas e entrevistas com ex-membros da organização.

Palavras-chave: Nova Esquerda. Peronismo. Marxismo. Violência Política. Luta armada. 
Introducción: el estudio de las Fuerzas Armadas Revolucionarias y sus aportes a la comprensión de los procesos de politización y radicalización en Argentina

Desde mediados de los 1950 hasta la última dictadura militar de 1976, Argentina vivió un período de gran conflictividad social e inestabilidad política, debido al agotamiento de su régimen de acumulación y a la crisis de legitimidad que atravesaron las instituciones democráticas tras la proscripción del peronismo en 1955. Todo ello, combinado con el proceso de modernización cultural, el impacto de la Revolución Cubana y otros movimientos de liberación nacional, generó transformaciones significativas en las prácticas y los discursos de actores sociales preexistentes y también la emergencia de otros nuevos. De hecho, desde el levantamiento popular conocido como "Cordobazo", en 1969, amplios sectores de trabajadores, la Iglesia, el campo cultural y universitario protagonizaron un proceso de activación social y politización dando lugar a un conjunto de movimientos de oposición de diverso orden que ha sido denominado "nueva izquierda" (TORTTI, 1999, 2014). Pese a su diversidad, que incluyó tanto la protesta social como la radicalización política, estos sectores convergieron en torno a un lenguaje y un estilo político común que expresaba sus demandas en términos de "liberación nacional”, “socialismo" y “revolución”. Su presencia alteró notablemente la dinámica política nacional, precipitando el fin de la dictadura militar que sucesivamente encabezaron Juan Carlos Onganía, Roberto Marcelo Levingston y Alejandro Agustín Lanusse (1966-1973). Las organizaciones armadas que surgieron por entonces, al desafiar el monopolio estatal de la violencia legítima y articularse con el movimiento de protesta social más amplio, fueron actores destacados del proceso. Entre ellas pueden mencionarse las Fuerzas Armadas de Liberación (FAL) y el Partido Revolucionario de los Trabajadores-Ejército Revolucionario del Pueblo (PRT-ERP), filiadas con la izquierda marxista, y las Fuerzas Armadas Peronistas (FAP), Descamisados y Montoneros, identificadas con la izquierda peronista. 
Este artículo analiza los orígenes y el desarrollo de una de estas organizaciones: las Fuerzas Armadas Revolucionarias (FAR), sobre la cual no se había realizado ningún trabajo académico antes del inicio de esta investigación ${ }^{1}$. Ahora bien, más allá del vacío bibliográfico, conviene comenzar planteando un interrogante: ¿por qué tiene sentido estudiar las FAR? Es decir, insertando esta experiencia en un campo de problemas mayor para sugerir los aportes de su abordaje.

Las FAR fueron fundadas por grupos que rompieron con la izquierda marxista a comienzos de los 1960 - el Partido Comunista (PC) y el Movimiento de Izquierda Revolucionaria-Praxis (MIR-Praxis) - y que, entre 1966 y 1969, participaron de distintas experiencias guevaristas. En 1970, estos grupos se fusionaron y se presentaron públicamente con la toma de Garín (Buenos Aires), dejando pintada en las paredes del pueblo la consigna sanmartiniana que desde entonces los identificaría: Libres o muertos, jamás esclavos. Al año siguiente, asumieron al peronismo como identidad política propia desde una perspectiva marxista y un proyecto político cuyo objetivo final era el socialismo. Dichas consideraciones fueron expuestas en "Los de Garín” (FAR, 1971b), un reportaje sumamente difundido en la época que, además, dio lugar a una intensa polémica con el PRT-ERP. Se trató de uno de los debates político-intelectuales más importantes originados en el campo de las organizaciones armadas argentinas.

Paralelamente, las FAR desarrollaban una intensa actividad. Llegaron a crear regionales en distintos lugares del país como Buenos Aires, Córdoba, Tucumán, Santa Fe y Mendoza, al tiempo que desde 1971 comenzaron a plantearse cómo articular su accionar más orgánicamente con grupos de activistas de base. Por entonces, también intentaban converger con FAP, Montoneros y Descamisados en una instancia de coordinación denominada Organizaciones Armadas Peronistas (OAP). Tras la frustración de esta experiencia, en 1973, las FAR se fusionaron con Montoneros.

\footnotetext{
${ }^{1}$ Este artículo constituye una apretada síntesis de mi tesis doctoral (González Canosa, 2013a), realizada bajo la dirección de María Cristina Tortti y Aníbal Viguera en el Doctorado en Ciencias Sociales de la Facultad de Humanidades y Ciencias de la Educación de la Universidad Nacional de La Plata (UNLP), Argentina. A ambos les agradezco su supervisión y apoyo y también al Consejo Nacional de Investigaciones Científicas y Técnicas (CONICET), por haber financiado durante 5 años esta investigación.
} 
En principio, en vistas del itinerario mencionado, puede considerarse a las FAR como exponente de un conjunto de problemáticas que fueron clave en la Argentina del período: la identificación con el peronismo de vastos sectores de izquierda, particularmente de sus filas juveniles de clase media ilustrada, la legitimación de la violencia como forma de intervención política y la opción por la lucha armada como modalidad específica de ponerla en práctica.

Pero, además, el análisis de las FAR nos permite iluminar nuevas facetas dentro del propio campo de las organizaciones armadas peronistas. Estas organizaciones surgieron al calor de la reconfiguración de distintas tradiciones político-culturales, fundamentalmente: el peronismo, el catolicismo, el nacionalismo y la izquierda. Los estudios sobre FAP y Montoneros han mostrado que la primera organización fue emergente del proceso de radicalización del propio campo peronista (LUVECCE, 1993; PÉREZ, 2003; RAIMUNDO, 2004) y que la segunda lo fue de las transformaciones ocurridas en el mundo del nacionalismo y los cristianos postconciliares (GILLESPI, 1998; LANUSSE, 2005; DONATELLO, 2010; DONATELLO, CATOGGIO, 2010). La mayoría de los integrantes de Descamisados provenía también de la militancia católica, tanto en agrupaciones universitarias como en la Democracia Cristiana (SALAS; CASTRO, 2011). Mientras tanto, el itinerario de gestación y desarrollo de las FAR expresa un cauce de radicalización política distinto del que dio lugar al resto de las organizaciones armadas peronistas: las profundas reconfiguraciones operadas en la cultura política de la izquierda argentina del período.

Teniendo en cuenta este marco problemático, el trabajo analiza la historia de las FAR considerando el período que va desde los primeros 1960, cuando comenzaron a perfilarse sus grupos fundadores, hasta las elecciones de marzo de 1973, cuando la dinámica política nacional cambia notablemente y la realidad de la organización ya está signada por la fusión con Montoneros.

Nuestro problema de investigación articula dos ejes analíticos, que se abordan considerando tanto sus orígenes como su desarrollo e implicancias. Uno de ellos, de orden político-ideológico, remite al proceso de identificación de las FAR con el peronismo, cuyos antecedentes se remontan a las reinterpretaciones del fenómeno 
realizadas por sus grupos fundadores. El otro, de orden político-organizativo, aborda sus prácticas políticas y dinámicas de funcionamiento como organización armada y su comprensión requiere considerar los cambios de estrategias políticas ensayadas por sus grupos fundadores.

A lo largo del trabajo, sostendremos tres hipótesis o ideas-fuerza vinculadas con los ejes arriba señalados, que remiten a distintos períodos del itinerario de gestación y desarrollo de las FAR. 1) Que la constitución de la organización implicó que sus fundadores transitaran un proceso de doble ruptura respecto de los partidos donde habían iniciado su militancia en los 1960. 2) Que, más allá de esas rupturas, las nuevas posturas conservaron ciertas huellas de origen que le imprimieron a las concepciones y el estilo de accionar de las FAR su perfil particular, sobre todo durante sus primeros años (1970-1971). Y 3) finalmente, que tal perfil distintivo no permaneció indemne frente a la dinámica política nacional. Por el contrario, a la luz de la encrucijada política delineada hacia 1972, tanto por el desafío electoral planteado por Lanusse como por las disyuntivas provocadas por la estrategia de Juan Domingo Perón, los planteos de las FAR experimentaron sustanciales variaciones que contribuyen a explicar su posterior acercamiento a Montoneros. Fundamentaremos estas tres ideas-fuerza en los distintos apartados del artículo.

El enfoque analítico y la forma de problematizar el tema determinaron la periodización de la investigación que, si bien se centra en las FAR (1970-1973), se retrotrae hasta comienzos de los 1960, cuando comenzaron a delinearse sus grupos fundadores. Con ello se buscó reponer las tramas sociales y políticas al calor de las cuales se forjó la organización. Es decir, abordar la génesis y enfatizar la dimensión procesual de fenómenos que terminarán por delinearse y cobrar visibilidad a principios de los 1970. Y, al mismo tiempo, evitar los determinismos y las miradas teleológicas, tratando, como señala Torre (2011, p. 245), de devolverle al pasado la incertidumbre acerca del futuro que experimentaban los actores. En la misma línea, y más allá de los esquemas binarios que oscilan entre la celebración y la condena, se buscó construir una perspectiva de tipo comprensiva, atenta al sentido que los actores le atribuyeron a sus prácticas y discursos en aquel contexto. 
Para realizar esta investigación se apeló a una estrategia metodológica cualitativa. Se relevaron fuentes escritas de diverso orden: diarios y revistas de alcance nacional, documentación pública y de circulación interna de las FAR, de otras organizaciones con que se vincularon y de los grupos donde militaron sus fundadores en los 1960. Además, se realizaron entrevistas semiestructuradas a miembros de las FAR y a informantes clave ${ }^{2}$.

\section{Los orígenes y el proceso de doble ruptura: de la izquierda insurreccional a la organización armada en vísperas de peronización (1960-1970)}

Hemos señalado que las FAR fueron emergentes de las reconfiguraciones de la cultura política de la izquierda argentina. De hecho, puede pensarse que su constitución responde a un proceso de doble ruptura respecto de esta tradición de izquierda de la que provienen sus fundadores: 1) tanto de sus formas de hacer política, pues iniciaron su militancia en partidos que privilegiaban los métodos legales de lucha y donde la violencia figuraba como recurso de última instancia ejercido masivamente tras una insurrección popular; 2) como de las tradiciones político-ideológicas de estos partidos, deudoras del pensamiento liberal y sumamente críticas del peronismo.

Para analizar este proceso de doble ruptura, distinguiremos dos etapas en los orígenes de las FAR. Un período más mediato (1960-1966), en que las trayectorias de sus dirigentes se entrelazan hasta perfilar los grupos fundadores de la organización; y otro más inmediato (1966-1970), cuando estos grupos participan de diversas experiencias guevaristas hasta formar la organización.

\footnotetext{
${ }^{2}$ Buena parte de las fuentes escritas no hubieran podido hallarse sin el trabajo de preservación y política de acceso público de instituciones como el Centro de Documentación e Investigación de la Cultura de Izquierdas en la Argentina (CeDInCl), la Comisión Provincial por la Memoria, que gestiona el Archivo de la Dirección de Inteligencia de la Policía de la Provincia de Buenos Aires y repositorios digitales como Ruinas Digitales (www.ruinasdigitales.com) y el Topo Blindado (http://eltopoblindado.com). En cuanto a las fuentes orales, realizamos 25 entrevistas a 17 testimoniantes distintos, 5 mujeres y 12 hombres de entre 60 y 70 años. Se trata de ex miembros de las FAR, compañeros de militancia de sus fundadores durante los sesenta y algunos informantes claves. Además, visualizamos 9 entrevistas en el Archivo Oral de Memoria Abierta ( 3 mujeres y 6 hombres). Considerando todas las entrevistas mencionadas, reunimos testimonios relativos a la mayoría de las regionales de las FAR, aunque predominan los de aquellos que militaron en Buenos Aires, donde la organización alcanzó su mayor desarrollo.
} 
Los pasos previos: itinerarios político-ideológicos en la gestación de los grupos fundadores de las FAR (1960-1966)

Los grupos fundadores de las FAR fueron tres. El más numeroso lo dirigía Carlos Olmedo y estaba integrado por ex miembros del PC, entre ellos Roberto Quieto. Se trata de militantes cuyas trayectorias políticas tienen un mismo origen y que, motivados por temas afines, rompieron con el partido en los primeros 1960. Desde entonces circularon por diversos ámbitos del comunismo disidente, estableciendo una serie de redes en base a las cuales se delineó el grupo, ya bajo la dictadura de Onganía. Estos ámbitos fueron "Vanguardia Revolucionaria” (VR), grupo político de existencia efímera escindido del PC en 1963; el Sindicato de Prensa de Buenos Aires, desvinculado de la órbita del partido en 1965; y la revista político-cultural La Rosa Blindada, cuyos integrantes fueron expulsados en $1964^{3}$.

Otro de los grupos fundadores de las FAR, donde se destacaban las figuras de Marcos Osatinsky y Alfredo Levenson, también fue formado por disidentes del PC. En este caso, el grupo se gestó al calor de una ruptura de la Federación Juvenil Comunista (FJC) producida en 1966 y ya bajo el impulso de viajar a Cuba para participar de algún proyecto liderado por Guevara ${ }^{4}$.

El último grupo fue el encabezado por Arturo Lewinger, cuyos activistas habían iniciado su militancia en el MIR-Praxis liderado por Silvio Frondizi. Se trató de un espacio político crítico de las fuerzas tradicionales de la izquierda y cuyo rasgo distintivo era el énfasis en la formación teórica y política. Hacia 1961, estos militantes impulsaron junto a

\footnotetext{
${ }^{3}$ En el primer núcleo, del que participó Carlos Olmedo, con la intención de apoyar la campaña de Guevara en Bolivia, estaban Roberto Quieto, Antonio Caparrós, Oscar Terán, Eduardo Jozami, Lila Pastoriza y pocos activistas más. No todos ellos ingresaron a las FAR pero fueron figuras centrales en la gestación de su grupo fundador y en el mundo de rupturas de la izquierda de la época. Roberto Quieto, Lila Pastoriza y Antonio Caparrós participaron de VR; Carlos Olmedo, Oscar Terán y Caparrós de La Rosa Blindada (al igual que Juan Gelman, quien luego también ingresará en las FAR) y Eduardo Jozami del Sindicato de Prensa, al cual Roberto Quieto se sumó como asesor legal. Posteriormente, a este núcleo original se incorporaron, entre otros, Osvaldo Olmedo, Eusebio Maestre, Juan Pablo Maestre, Mirta Misetich, Alberto Camps, Leonardo y Jorge Adjiman, María Angélica Sabelli, Isabel, Carlos y Liliana Goldemberg, Sergio Paz Berlín, Pilar Calveiro, Horacio y Alcira Campiglia, Claudia Urondo, María Adelaida Viñas, María Antonia Berger y Teresa Meschiatti, todos ellos militantes de las FAR.

${ }^{4}$ En este grupo, además de Marcos Osatinsky y Alejo Levenson, estaban Sara Solarz, Marcelo Kurlat y Mercedes Carazo. También participaron de la ruptura de la FJC y viajaron con ellos a Cuba otros militantes que luego no ingresaron a las FAR como Alfredo Helman, Alfredo Moles, Jorge Gadano y Alicia Gillone.
} 
Frondizi un viraje en la orientación discursiva, programática y organizativa del MIR-Praxis. Por un lado, la organización comenzó a transitar desde un marxismo crítico de corte humanista e influencias trotskistas a una estrategia discursiva de resonancias nacionalpopulares, buscando ubicarse como momento superador de una genealogía cuyos antecedentes eran el yrigoyenismo y el peronismo. Y, por otro lado, pasó de la práctica básicamente teórica al énfasis en el trabajo político de inserción territorial, sobre todo en barrios y villas del Gran Buenos Aires y La Plata. Profundizando aún más los planteos en línea nacional-popular y bajo el impulso de pasar a la acción, en 1964 parte del grupo conformó un espacio político autónomo denominado Tercer Movimiento Histórico (3MH). El 3MH fue una breve y peculiar experiencia que, influenciada por el nacionalismo popular y convencida de que la revolución requeriría el respaldo de las armas, llegó a depositar expectativas en la idea de un golpe militar de base popular y estilo nasserista ${ }^{5}$. Tras perder sus esperanzas en la existencia de sectores "nasseristas" en el Ejército con la dictadura de Onganía y dispuestos a conformar un "ejército popular", viajaron a Cuba buscando sumarse al proyecto continental de Guevara ${ }^{6}$.

En términos del proceso de doble ruptura señalado, en este período el tema dominante fue la opción por la lucha armada, discusión en que la Revolución Cubana tuvo un impacto notable. Leída desde una dinámica política signada por proscripciones y dictaduras, forjadora de nuevas convicciones o ejemplo histórico usado para confirmar creencias previas, es difícil exagerar su influencia entre estos militantes. Aún así, el impacto inicial del proceso cubano tuvo menos que ver con el método guerrillero que con el tema de las “etapas” de la revolución, el primer debate en juego. Durante los primeros

\footnotetext{
${ }^{5}$ Entre los militantes del grupo, además de Arturo Lewinger se encontraba su hermano Jorge Omar Lewinger, Luis Piriz, Humberto D'Hippolito, Elida D'Hippolito, Eva Gruszka y Roberto Pampillo. Todos siguieron el itinerario señalado excepto Pampillo, que se sumó después. Posteriormente, Piriz y D'Hippolito se separaron del grupo, ingresando el primero al PRT-ERP y el segundo a Descamisados.

${ }^{6}$ Un análisis detallado sobre la gestación de los 3 grupos mencionados en González Canosa (2011 y 2012). Aquí, limitamos el análisis a los dos ejes indicados en la introducción, para lo cual nos basamos en una diversidad de fuentes. Para el grupo liderado por Carlos Olmedo: periódico Nuestra Palabra (1963-1966), Vanguardia Revolucionaria (1963), periódico Vanguardia Revolucionaria ( $N^{\circ} 1$ y 2,1964$)$, revista Táctica ( ${ }^{\circ} 1$, 1964), revista La Rosa Blindada ( $N^{\circ} 1$ al 9, 1964-1966), entrevistas de la autora a Eduardo Jozami (2007), "Militante de VR" (2009 y 2010), Carlos Ábalo (2009 y 2010) y Lila Pastoriza (2010). Para el grupo de la FJC: Nuestra Palabra (1966), entrevistas de la autora a Alfredo Moles (2010 y 2011), Sara Solarz (2012) y Mercedes Carazo (2012). Y, para el grupo liderado por Arturo Lewinger: Frondizi (1961), periódico Movimiento ( $\left.\mathrm{N}^{\circ} 1 \mathrm{al} 4,1961\right)$, Lewinger et al. (1964), Lewinger et al. (1966), entrevistas de la autora a Jorge Lewinger (2007), Alberto Ferrari Etcheberry (2007) y Mario Rabey (2007).
} 
sesenta, estos militantes forjaron la convicción - los disidentes del PC - o bien confirmaron creencias previamente sostenidas en clave trotskista - los provenientes del MIR-Praxis - de que la revolución en Argentina sería un proceso de liberación simultáneamente nacional y social. En todos los casos, se impugnaba la línea política del PC, que separaba en dos etapas las tareas de liberación nacional y las socialistas, impulsando en lo inmediato una revolución "democrático-nacional”, donde las alianzas con la burguesía nacional jugaban un rol central.

Saldada la discusión contra la concepción "etapista” del PC y planteada la “actualidad" de la revolución socialista, el debate que se impuso fue el de las "vías" hacia ella. También en este caso se refutaba otro planteo que el PC argentino sostenía en línea con la política soviética: la posibilidad de acceder al socialismo por vías pacíficas. No obstante, bajo esta perspectiva los grupos mencionados vislumbraron alternativas sumamente diversas: desde estrategias insurreccionales basadas en el trabajo político de inserción territorial (el MIR-Praxis tras 1961) hasta la apuesta por un golpe militar de estilo nasserista (el $3 \mathrm{MH})$. En este sentido, el primer acercamiento hacia la estrategia guerrillera provino de los disidentes del PC. Nos referimos a los contactos establecidos por VR con el Ejército Guerrillero del Pueblo, un núcleo guerrillero instalado en Salta que fue impulsado por Guevara en 1963 como eslabón de su estrategia continental.

Como puede verse, la convicción de que la revolución requeriría formas concretas de violencia estaba instalada antes de la dictadura militar que instauró Onganía. Sin embargo, no podría exagerarse su impacto en la precipitación de todas estas cuestiones. Desde entonces, el grupo de Lewinger descartó la existencia de sectores "nasseristas" en el Ejército y optó por el camino cubano, al tiempo que los grupos escindidos del PC hallaban el contexto propicio para poner en práctica su convicción de que la lucha armada era la única vía al socialismo.

Si bien la opción por la lucha armada fue el tema dominante del período, las discusiones sobre el peronismo no estuvieron ausentes. Más allá de los matices propios de cada grupo, lo que puede verse es un proceso de reinterpretación del peronismo que implicó la revalorización del papel que había jugado entre las masas. Desde entonces, ya no lo consideraron un "desvío" en la conciencia de la clase obrera - concepción que le 
atribuían a la izquierda tradicional - sino un "momento" positivo en su larga marcha al socialismo. De todos modos, todos creían que el rol histórico del peronismo había concluido y debía ser superado. Ya sea a través de un amplio movimiento popular que sintetizara los avances del yrigoyenismo y el peronismo (el MIR-Praxis tras 1961 y el 3MH) o de la gestación de una nueva vanguardia política (como proponía VR).

\section{Las armas secretas: los orígenes guevaristas de las FAR (1966-1970)}

Es sabido que la Revolución Cubana cambió el panorama de la izquierda latinoamericana, erosionando la hegemonía detentada por los partidos comunistas alineados con la Unión Soviética. Sobre todo, al poner en cuestión el tema de las “etapas” de la revolución, sosteniendo que implicaría un proceso de liberación simultáneamente nacional y social; y también el de sus "vías", reinstalando el tema de la lucha armada. En este marco, y al calor de las incursiones de Guevara en África y Bolivia, cobró auge la llamada "teoría del foco", basada en la perspectiva guevarista y popularizada por textos de gran divulgación que contaron con apoyo cubano como Revolución en la Revolución de Regis Debray (1967). Mencionaremos brevemente un conjunto de tópicos usualmente asociados con la concepción del "foco insurreccional”.

En principio, la idea de que en la mayoría de Latinoamérica estaban dadas las condiciones objetivas para la revolución, mientras que las condiciones subjetivas terminarían de consolidarse al calor de la lucha, cuya modalidad privilegiada sería la acción armada. En segundo lugar, la consideración del campo como escenario privilegiado de la lucha armada, pues sólo allí la guerrilla podría convertirse en ejército popular capaz de vencer al ejército regular. Por ello, si bien Guevara señalaba la importancia de la lucha en las ciudades, sostenía su subordinación a la guerrilla rural, dirección político-militar del proceso revolucionario aún en los países predominantemente urbanos. A su vez, si bien Guevara destacaba que la premisa básica de la guerra de guerrillas era el apoyo popular, es necesario subrayar el papel clave que otorgaba al pequeño núcleo de hombres que iniciaba la guerrilla y el ejemplo de la acción armada como forma no exclusiva, pero sin dudas central de conquistar tal apoyo. Por último, a estas premisas debe sumarse que la 
guerra de guerrillas sería tanto una lucha prolongada como de escala continental, puesto que el intervencionismo norteamericano no reconocía fronteras.

Más allá de la amplia influencia que tuvo la Revolución Cubana en Argentina y de la reivindicación de la figura de Guevara que hicieron grupos armados y no armados de la izquierda y el peronismo, pocos de ellos tuvieron un vínculo tan directo con sus últimos proyectos como los que fundaron las FAR. De hecho, entre 1966 y 1967, los 3 grupos mencionados viajaron a Cuba y se entrenaron militarmente buscando integrarse al Ejército de Liberación Nacional (ELN) que Guevara lanzó en Bolivia. Si bien la muerte del “Che" los sorprendió sin poder concretar esos planes, su participación en un proyecto de inspiración guevarista no culminó allí. Junto con otros grupos también entrenados en la isla, entre 1968 y 1969 formaron parte de la sección argentina del ELN que, tras la muerte de Guevara, relanzó Inti Peredo. En el marco de esa estructura, con base en Bolivia pero con intenciones de proyección continental, estos grupos realizaron entrenamiento, tareas logísticas para la instalación de un foco guerrillero en Tucumán y acciones armadas urbanas sin firmar, por lo que su existencia permaneció en el anonimato. La más importante de estas acciones, por su espectacularidad y por la ausencia de víctimas, fue el incendio de 13 supermercados Minimax en junio de $1969^{7}$. Tras la muerte de Inti Peredo este mismo año, la sección argentina del ELN se desarticuló y, abandonando la perspectiva continental, los 3 grupos cuyo itinerario hemos reconstruido se fusionaron fundando el núcleo central de la organización. Pronto sumaron nuevos contingentes militantes en Córdoba, Tucumán y La Plata y en 1970 se presentaron públicamente bajo la sigla FAR con el copamiento de Garín ${ }^{8}$.

En términos de los ejes propuestos para analizar los orígenes de las FAR, lo que se

\footnotetext{
7 Un análisis detallado del itinerario guevarista de estos grupos puede verse González Canosa (2013b). Para la reconstrucción del proyecto del ELN argentino fue central su documento "Tareas para la implementación de un frente guerrillero en la Argentina”, 1969, Archivo de la Dirección de Inteligencia de la Policía de la Provincia de Buenos Aires (DIPBA), Mesa DS, Carpeta Varios, Legajo 110 y las entrevistas de la autora a "Militante de FAR 1" (2012), “Militante de FAR 2" (2012) y Ricardo Rodrigo, coordinador del ELN en Argentina (2012).

${ }^{8}$ Entre los activistas del grupo Cordobés se destacarán Juan Julio Roqué, Alfredo Kohon, Carlos Astudillo, Mario Lorenzo, Juan y la "Bruja” Koncurat, Héctor Pedro Pardo, Pancho Ribas y Eberto Arrascaeta. Entre los de Tucumán, varios ya peronistas y formados en el catolicismo posconciliar: Luis Fernando Martínez Novillo, José Carlos Coronel, Miguel Ángel Castilla, Martín Gras, Alberto Simón Savransky, Nélida y Agustín Villagra. Y, entre los primeros militantes de La Plata: Eduardo Jensen, Uriel Rieznik, Mirta Clara, Néstor Sala y Víctor Kein.
} 
observa en estos años es el pasaje desde una estrategia continental basada en la guerrilla rural, hacia otra de alcance nacional que terminará privilegiando la lucha urbana. Diversos factores convergieron impulsando ese tránsito: la muerte de Inti Peredo y la desarticulación del ELN, el propio antecedente que éste había sentado en términos del accionar urbano, la influencia de la guerrilla urbana de los Tupamaros y los balances sobre el fracaso de los movimientos latinoamericanos basados en la guerrilla rural como forma dominante de lucha, incluyendo el caso del propio Guevara en Bolivia. A ello se sumó el efecto "nacionalizador" producido por la revalorización de la experiencia peronista, acicateada por la combatividad mostrada por la clase obrera durante el Cordobazo y por los debates que los grupos fundadores de las FAR iniciaron con las FAP. Desde entonces, la organización sostendrá que la continentalización de la lucha sólo podría darse a partir de la coordinación de movimientos nacionales iniciados de modo independiente y en sintonía con las particularidades de cada país (FAR, 1971a). A su vez, si bien la idea de montar un foco en el campo nunca desapareció como planteo estratégico, ya no orientará sus prácticas políticas concretas.

Si bien la opción por la lucha armada fue el tema dominante durante todo el período de los orígenes, las discusiones sobre el peronismo se acrecentaron con el cambio de década. De hecho, en los escritos de Carlos Olmedo de la época del ELN ya se insinúa la pista de análisis que guiará a las FAR en su interpretación del peronismo: la “experiencia vivida" por los trabajadores bajo su gobierno y el papel jugado por esa identidad política tras 1955. Es decir, su rol como "indicador de clase", aquello que le había permitido al proletariado diferenciarse de la burguesía ([OLMEDO, 1968]). Aun así, fue recién en 1970 cuando la organización comenzó realmente a replantearse su relación con el movimiento. Por entonces afirmaba:

Para nosotros, para esa vanguardia [la que buscaban gestar], el camino de la identidad no es sino el de una doble identificación: la nuestra en los intereses históricos de la clase obrera y el pueblo y la del pueblo en las perspectivas de nuestra lucha, que es su lucha. Por eso nos teme el enemigo: somos pocos, pero late en nosotros la fuerza de los más. Y con los más daremos y ganaremos esta guerra ([OLMEDO, 1970]). 
Desde esta perspectiva, la organización afirmaba que su aspiración de formar parte de la vanguardia de la clase obrera y el pueblo sólo podía partir de "la propia experiencia de las masas, de su propio nivel de conciencia y expectativa". De aquel universo político en que las "masas interpretan su explotación, sus derechos y su destino". Por esta vía, y siguiendo el principio maoísta sintetizado en la consigna "de las masas a las masas", la organización comenzó a plantearse algunos interrogantes que, más allá de la cuestión armada y las distintas respuestas elaboradas, atravesaron a buena parte de la izquierda argentina del período:

\begin{abstract}
¿Aplicar en Argentina el principio “de las masas a las masas” implica sólo tomar las ideas más radicales y clasistas de las masas, hacerlas nuestras, convertirlas en el sentido de nuestra lucha, volver con ellas desarrolladas a las masas y recoger una y otra vez el saldo positivo que vaya dejando su experiencia enriquecida por los combates y todo el accionar de la vanguardia?, ¿O todo esto sólo se puede lograr presentándonos como peronistas (en el sentido en que la clase es peronista) y profundizando sin límites ese componente definitorio de la ideología de la clase? Discusión abierta y decisiva que arrojará sin dudas buenas guías para la acción eficaz a corto y largo plazo ([OLMEDO, 1970]) ${ }^{9}$.
\end{abstract}

Efectivamente, la “opción por el peronismo" - como la denominará el grupo -, ya insinuada en este escrito, quedó abierta un año más. Lo cual, como ocurrió con la definición de su estrategia político-militar, no sucedería sin que las FAR transitaran arduos debates internos.

\title{
II. Marxismo, peronismo y lucha armada: huellas de origen en la postura de las FAR (1970-1971)
}

Ahora bien, dado que en la historia las rupturas son siempre relativas, en el itinerario de gestación y desarrollo de las FAR pueden captarse cambios, como los que hemos analizado, pero también continuidades. De hecho, los nuevos planteos conservaron ciertas huellas de origen que le otorgaron a las concepciones y el estilo de

\footnotetext{
9 En esta cita y en la anterior nos referimos a los escritos "Notas para una valoración de la situación nacional” (1968) e "Informe de la Reunión Nacional de Mandos" (1970). Si bien los documentos no están firmados (se trata de trabajos mimeografiados hallados en el Archivo de la Dirección de Inteligencia de la Policía de la Provincia de Buenos Aires -DIPPBA), pudimos comprobar fehacientemente su autoría mediante el intercambio con ex militantes tanto de las FAR como del ELN argentino.
} 
accionar de las FAR su impronta distintiva, al menos durante sus primeros años (19701971). Básicamente: el marxismo como método de análisis de la realidad nacional y como prisma de interpretación del fenómeno peronista, y el legado guevarista como forma de pensar sus vínculos con sectores más amplios del movimiento social.

\section{El marxismo como método de análisis, el peronismo como identidad política y el socialismo como objetivo final}

Como señalamos, la identificación de las FAR con el peronismo se hizo pública a principios de 1971. Fue entonces cuando su conducción terminó de forjar una convicción y consiguió el consenso interno necesario para actuar en consecuencia: dada la historia reciente argentina, las posibilidades revolucionarias en el país sólo podían pasar por la radicalización del peronismo. Es decir, consideraban que entre peronismo y socialismo había continuidad y no ruptura. Aún así, las FAR asumieron el peronismo como identidad política propia de modo crítico, en consonancia con las resistencias y discusiones que de hecho venían atravesando desde $1970^{10}$. Esta visión crítica sobre el peronismo tenía que ver con una clara afirmación del socialismo como objetivo final de su lucha - que la doctrina de conciliación de clases trazada en 1945 parecía invalidar; su aversión hacia la dirigencia sindical y política del movimiento; su profundo rechazo a toda alianza con la burguesía nacional - que el gobierno justicialista había expresado y proclamado en su doctrina - y, sobre todo, con las desconfianzas que les despertaba la figura de Perón, a quien consideraban un "líder popular" capaz de conducir ciertos tramos del proceso de liberación y social, pero no un "líder revolucionario"11. Sin embargo, todas estas

\footnotetext{
${ }^{10}$ En esos debates internos tuvo cierto peso la cuestión regional. Básicamente, la incorporación de la regional tucumana - ya peronista - fue pensada estratégicamente por el núcleo fundador de la organización (la fusión de los 3 núcleos que hemos analizado) como modo de terciar en el debate que por entonces mantenía con el grupo recientemente integrado de Córdoba, caracterizado como "el más marxista" y reacio al peronismo.

${ }^{11}$ El tema de la valoración de Perón por parte de una organización como las FAR, es obviamente complejo. En general, la organización buscó mantener en sus escritos un delicado equilibrio entre valorar al líder y circunscribir su papel, de modo que fuera posible formar parte del movimiento sin tener que renunciar a su autonomía ni a sus propios objetivos estratégicos. Para ello apelaban a interpretaciones sobre las posiciones de Perón que ya estaban disponibles en la tradición del peronismo de izquierda. Interpretaciones donde, básicamente, Perón aparecía como un líder despojado de voluntad política propia, obligado a moverse en el "campo del sistema" con los recursos disponibles (la "superestructura política y sindical” del movimiento), lo cual volvía necesario que las fuerzas revolucionarias gestaran una alternativa por la que finalmente pudiera optar (FAR, 1971b, p. 68-69).
} 
cuestiones remitían al estado actual del peronismo, mientras que la decisión de las FAR se fundó en una apuesta por desarrollar sus potencialidades revolucionarias. En este sentido, se trató de una decisión y de una apuesta política en el sentido fuerte de ambos términos, de posibilidades sin garantías de éxito, cuya concreción, de acuerdo al tono de la época, dependería de la voluntad de los militantes. De su acción - junto con la de todos los que luchaban en la misma dirección - dependería que el peronismo se convirtiera en un movimiento de liberación nacional que condujera al socialismo. En este punto, existía una enorme confianza en que la propia dinámica del proceso revolucionario terminaría consolidando la claridad ideológica de los trabajadores y marginando tanto a la "burocracia” peronista como a la burguesía nacional. En realidad, entre todas las resistencias previas a su identificación con el peronismo y que persistieron después, el tema central siempre fue el liderazgo de Perón.

La identificación de las FAR con el peronismo se basó en un análisis donde se percibe claramente una de las huellas de origen del cauce de radicalización a través del cual se formó la organización. Nos referimos a los lentes marxistas desde los cuales construyó su visión sobre el peronismo y la posibilidad de conjugarlo con el socialismo. Estas consideraciones quedaron plasmadas en los documentos más conocidos de la organización, que aún hoy perviven en la memoria militante: "Los de Garín", las "13 preguntas a las FAR" (FAR, 1971C) y su polémica con el ERP (ERP [1971], 1973; FAR, [1971] 1973). Esta última supo condensar, de modo paradigmático, las controversias que separaban a los grupos de la izquierda marxista de aquellos que, como las FAR, se identificaban con el peronismo, pero reivindicando también su filiación con el marxismo.

La clave de la operación político-intelectual realizada por las FAR consistió en la consideración del marxismo como método de análisis de la realidad nacional y en la reivindicación del peronismo como identidad política de los trabajadores. Para ello, el marxismo fue negado como "bandera política universal" y ubicado exclusivamente en el lugar de la teoría. Se trató de un tipo de marxismo situado, especialmente sensible a la cuestión nacional y al tema de la experiencia para pensar la formación de la clase obrera. Desde estos lentes, las FAR construyeron el llamado “peronismo del pueblo”. Bajo esta denominación, expresaban su valoración de la experiencia forjada por los trabajadores en 
el marco del movimiento, donde creyeron encontrar la clave de interpretación del fenómeno peronista y su persistencia como identidad política popular. Se trataba de un análisis centrado en una dimensión política y simbólica más que material o económica. Desde su visión, durante el gobierno peronista, la clase obrera había tomado conciencia de su fuerza, sus derechos y su dignidad, experiencia que había visto clausurada tras el golpe de 1955. Desde entonces, esta experiencia vivida, y sobre todo su brusca interrupción, había contribuido a que los trabajadores ligaran la concreción de sus reivindicaciones económicas con la perspectiva de la conquista del poder político, politizando todos sus conflictos sociales. A su vez, sostenían que el pueblo argentino no era tanto "un pueblo hambreado, como un pueblo ofendido" y que lo que generaba conciencia no era tanto la miseria como la comprensión de que esta miseria constituía una injusticia. Para las FAR, ése era el principal aporte que la experiencia peronista le había brindado al pueblo: "la posibilidad de comparar, cotejar y desmentir"; de percibir que la explotación era un fenómeno histórico ligado a intereses concretos y, por tanto, susceptible de transformación. En definitiva, sostenían que era en esta experiencia donde latían, "en estado práctico", los elementos de la conciencia obrera que de ser radicalizados podían conducir al socialismo (FAR, 1971b, p. 67-68). De este modo, las FAR se sumaban a la apuesta por ligar peronismo y socialismo que, de modo más o menos unívoco, hacía tiempo surgía entre distintas corrientes de la izquierda peronista.

Ahora bien, todo ello era por ahora sólo una posibilidad, una apuesta política por concretar aquello que el peronismo podía llegar a ser, ya que para la organización esta conciencia política de los trabajadores que el peronismo había contribuido a forjar no era aún una conciencia socialista. De allí que señalaran claramente las limitaciones de aquella experiencia peronista del pueblo. Estas limitaciones eran dos y justificaban el rol que las FAR buscaban jugar. Por un lado, las carencias doctrinarias del peronismo, que remitían a la necesidad del marxismo como instrumento de análisis; es decir, la herramienta que la organización quería aportarle al movimiento. Y, por otro, la precariedad de sus formas organizativas y métodos de lucha, que apuntaba a la necesidad de conformar una vanguardia político-militar; es decir, el Ejército del Pueblo que las FAR querían contribuir a gestar. 


\section{La acción armada como ejemplo}

Durante 1970 y buena parte de 1971, tanto las FAP como Montoneros y FAR funcionaron como "focos" relativamente aislados de la población. Por supuesto, eran el emergente de una trama de conflictividad social y política más amplia y todas le otorgaban un sentido político intrínseco a su accionar armado. Además, muchos de sus miembros conservaban relaciones con sus previas redes de militancia y todas las organizaciones contaban con colaboradores que buscaban sumarse a sus filas. A su vez, los lazos que lograron consolidar desde 1972 con activistas estudiantiles, barriales y obreros fueron notables, sobre todo en el caso de Montoneros.

Pero más allá de esto, lo que queremos indicar es que en el período señalado su accionar fundamental se desarrolló de modo paralelo a las diversas formas de lucha popular, aun cuando buscaran acompañarlas ${ }^{12}$.

Inclusive, tal fue el diagnóstico que aquellas trazaron sobre su propia práctica. Hacia 1971, Montoneros afirmaba que por entonces se abría un nuevo período: “el comienzo de la transición entre el 'foco' guerrillero como método y la 'infección' generalizada del mismo en el seno del pueblo" (MONTONEROS, 1971, p. 370). Para las FAP, se trataba de "pasar de la etapa del foco como generador de conciencia a la etapa de la guerra popular prolongada" (FAP, 1971, p. 227). Por su parte, las FAR declaraban que "la superación de la etapa en que la guerrilla opera como foco relativamente aislado de las masas no se decreta de palabra", subrayando las dificultades que tal proceso entrañaba (FAR, 1971c, p. 3). También fue este el año en que dichas organizaciones comenzaron a esbozar ciertas concepciones y alternativas organizativas para superar aquella situación. Bajo la idea de construir una herramienta política autónoma para la clase obrera peronista, las FAP lanzaron la Alternativa Independiente, una propuesta de fuerte impronta "basista", y Montoneros incluyó las Unidades Básicas Revolucionarias (UBR) en su estructura organizativa.

Pueden hallarse motivos diversos para explicar esta situación inicial y el intento de revertirla. En el primer caso, tanto la necesidad de consolidar la infraestructura de

\footnotetext{
${ }^{12}$ Excluimos de esta apreciación a Descamisados, ya que, por lo que se sabe, su accionar político-militar fue muchísimo menor y su postura "movimientista" coincidía con su interés en el desarrollo de un trabajo político de inserción territorial (ver Salas y Castro, 2011).
} 
organizaciones recientes, como concepciones políticas más generales. En el segundo, sin dudas, estaba en juego la necesidad de responder al desafío planteado por Lanusse, quien, con el lanzamiento del Gran Acuerdo Nacional (GAN), en marzo de 1971, y la posibilidad de una apertura electoral, buscaba detener la confluencia entre movimiento social y política revolucionaria, canalizando institucionalmente la protesta popular para aislar a la guerrilla.

Lo que sostenemos aquí es que la lógica de accionar de las FAR no se debió solamente a la necesidad de consolidar su infraestructura, sino a una concepción política más amplia, donde es perceptible la otra huella de origen a la que hemos aludido: la huella guevarista. En este sentido, más allá de los debates sobre el alcance nacional o continental de la lucha y sobre su forma rural o urbana, las FAR conservaron como marca de origen de su itinerario guevarista las enormes potencialidades atribuidas a la acción armada como "foco" irradiador de conciencia entre las masas. Lo cual puede observarse en sus escritos de circulación interna ([OLMEDO, 1970]; FAR, [1970]), en las reelaboraciones del legado guevarista que hicieron en sus documentos públicos (FAR, 1971a, 1971b y 1971c) y en la lógica de sus prácticas políticas de entonces.

En términos generales, esta concepción se sustentaba en la idea de que una organización revolucionaria debía elegir los medios "más eficaces" de lucha política, que consistían justamente en la acción armada (FAR, 1971b y 1971C). En este sentido, si bien se enfatizaba que todas las formas de lucha eran importantes, la acción armada era considerada la principal por lo que, en definitiva, todas las demás debían encuadrarse en la perspectiva de la construcción del Ejército Popular. Respecto de las masas, si bien para las FAR gracias al peronismo la clase obrera y el pueblo tenían una conciencia política que trascendía lo corporativo, esto no implicaba que su mayoría luchara por objetivos socialistas. Ello se lograría al calor del proceso de liberación, durante el cual la acción armada jugaría un rol central como "foco irradiador de conciencia acerca de la posibilidad del cambio revolucionario" (FAR, 1971C, p. 3). Desde esta perspectiva, de modo pronunciado durante sus primeros años y con persistencias después, las FAR consideraban que lo central era transmitirle al pueblo una metodología - la lucha armada -, lo cual se lograría básicamente a través del ejemplo de su accionar armado. Durante 
aquellos primeros años, la relación orgánica con las masas se preveía para un período posterior, luego de una fuerte consolidación interna. $Y$, además, creían que se lograría no tanto en base a un trabajo político de inserción en ámbitos gremiales, barriales o estudiantiles, sino a través de la atracción que generaría su accionar político-militar ${ }^{13}$.

La generación de vínculos orgánicos con sectores sociales más amplios comenzó a plantearse como desafío que demandaba una respuesta política específica recién avanzado el año 1971. Por entonces, además de continuar con las acciones armadas, las FAR se propusieron impulsar otros 2 procesos para reposicionar a la organización en el contexto aperturista generado por el GAN. Por un lado, intensificar su acercamiento con el resto de las organizaciones armadas peronistas. Esta política tuvo un primer avance en junio, con la creación de las OAP, aunque la experiencia no alcanzó el año debido a diferencias políticas. Y, por otro, la iniciativa que nos interesa subrayar aquí: avanzar en la articulación de la organización político-militar con agrupaciones de activistas de base (FAR [Regional Córdoba], s/f. [1971]).

Según las FAR, la idea de "articulación" expresaba el tipo de relación que por ahora podía plantearse entre organizaciones armadas y de base. Ello implicaba evitar tanto la unificación como la división del trabajo entre unas y otras. Desde su visión, plantearse una fusión inmediata implicaba desconocer la diversidad de formas organizativas resultante de las tareas encaradas, que todavía exigían niveles de seguridad y militantes con formaciones distintas. A su vez, planteaban que dividir el trabajo entre ambas los llevaría a disociar lo político de lo militar, retrasando tanto el "alza de la militarización" que debía darse en los grupos de base para que fueran menos vulnerables a la represión, como la capacidad de las organizaciones guerrilleras para jugar su papel de conducción política (FAR, 1971C, p. 4). Los riesgos que buscaban evitar eran dos. Por un lado, sustituir a las agrupaciones de base, reemplazando con su accionar militar los cambios en los métodos de lucha que ellas mismas debían protagonizar. Por otro, que la propia organización terminara constituyéndose exclusivamente como "brazo armado" del movimiento popular (FAR [Regional Córdoba], s/f. [1971]).

\footnotetext{
${ }^{13}$ Un análisis más amplio sobre las prácticas político-militares de las FAR durante sus primeros años, basado en un relevamiento periodístico de sus acciones, documentos y entrevistas, puede verse en González Canosa (2016).
} 
Además de los contactos más o menos aislados que comenzaban a entablarse con activistas en distintas regionales, podemos encontrar un indicio temprano de la política de articulación de las FAR en la zona de La Plata. Allí, a mediados de 1971, se conformó el Frente de Agrupaciones Eva Perón, de actuación en diversas facultades de la ciudad. Esta agrupación estudiantil estrechó rápidamente vínculos con las FAR donde, de hecho, ya militaban o comenzarían a hacerlo varios de sus fundadores. De todos modos, hacia fines de 1971, las FAR no habían avanzado mucho más respecto de sus relaciones con sectores sociales más amplios. Ni en términos prácticos ni en cuanto a sus conceptualizaciones teóricas. De hecho, la misma noción de articulación remitía a una idea muy general que aún no planteaba grandes cambios en la lógica de sus prácticas político-militares, ni instancias organizativas específicas para lograr ligazones orgánicas con las masas.

Ahora bien, como veremos a continuación, los planteos analizados experimentaron variaciones a partir de 1972. Se trata de un momento político clave para observar la reorientación de algunas posiciones de las FAR que facilitarán su fusión con Montoneros.

\section{De la perspectiva electoral hacia la fusión con Montoneros (1972-1973)}

Como señalamos, las concepciones y el estilo de accionar que caracterizaron a las FAR, durante sus primeros años, no permanecieron indemnes frente a la encrucijada política que terminó de perfilarse hacia 1972. Para las organizaciones armadas del peronismo, esta encrucijada se articuló a partir de 2 factores centrales. Por un lado, el avance de las tratativas en torno a la apertura electoral, proceso a través del cual Lanusse entreveía la posibilidad de evitar la convergencia entre protesta social y política revolucionaria. Por otro lado, la estrategia de Perón, quien en ese contexto impulsaba una ofensiva política tendiente tanto a la reorganización del propio movimiento como a la ampliación de sus alianzas políticas y sociales. Alianzas que excedían largamente a los sectores juveniles del movimiento y a la clase obrera, los actores que concitaban las expectativas de las organizaciones armadas. Ambos factores contribuyeron a delinear uno de los mayores desafíos que experimentaron las organizaciones armadas peronistas: 
cómo ampliar sus bases de sustentación para evitar el aislamiento respecto del peronismo y el movimiento social más amplio al que parecía conducirlas la nueva coyuntura.

En el marco de esta encrucijada, las 3 líneas de acción esbozadas por las FAR cobraron mayor ímpetu y renovados sentidos. Nos referimos a: 1) la realización de acciones armadas, tanto de pequeña como de gran envergadura que continuaron aún en el contexto preelectoral - la fuga del Penal de Rawson en agosto de 1972 es un ejemplo ${ }^{14}$; 2) avanzar en la convergencia con otras organizaciones peronistas, perspectiva que tras la frustración de las OAP derivaría en un largo proceso de fusión con Montoneros concretado en octubre de 1973; y 3) consolidar vínculos más orgánicos con sectores combativos del movimiento popular. En consonancia con esta última línea de acción, en 1972 las FAR idearon una estructura organizativa intermedia entre el nivel de militancia armado y no armado. Se trató de los "comandos de apoyo", tal como Montoneros había hecho lo propio con las UBR en 1971. Sin embargo, a diferencia de aquellas, que buscaban convertirse en "conducción táctica” de la movilización popular, la función que las FAR le atribuían a estos comandos era contribuir al fortalecimiento de la organización armada mediante apoyo logístico y la realización de operativos de poca envergadura (FAR, 1972). Además, según las entrevistas, no tuvieron una realidad práctica muy extendida. En este sentido, tanto los documentos de la organización como la menor profundidad de los cambios organizativos encarados en relación con las tareas de articulación sugieren que la visión de la acción armada como foco irradiador de conciencia adquirió mayor pregnancia en las FAR que en el resto de las organizaciones armadas peronistas. Ya avanzado el año 1972, en plena campaña electoral, la otra iniciativa que las FAR sumaron en este sentido, también de modo rezagado respecto de Montoneros, fue la militancia de inserción territorial en Unidades Básicas del peronismo.

A esta reorientación de la postura de las FAR hay que sumarle dos cambios que también facilitarán el acercamiento a Montoneros. Ambos deben comprenderse

\footnotetext{
${ }^{14}$ El 15 de agosto de 1972, en un operativo de gran espectacularidad, 6 dirigentes de FAR, Montoneros y ERP se fugaron de la cárcel de máxima seguridad de Rawson y tomaron un avión que desviaron hacia Chile, país gobernado entonces por Salvador Allende, partiendo luego a Cuba. Una semana después, los otros 19 guerrilleros que no lograron fugarse en este operativo fueron fusilados en la Base Aeronaval Almirante Zar, episodio popularmente conocido como "La Masacre de Trelew".
} 
atendiendo tanto a la renovada importancia adquirida por las estructuras institucionales del peronismo en la coyuntura preelectoral, como a la alianza de clases esbozada por Perón en aquel contexto.

Por un lado, la idea de que no había que desechar el trabajo político en las “estructuras formales" del movimiento (políticas y sindicales). De hecho, ya en sus comunicados de abril de 1972, las FAR proclamaban que las organizaciones armadas y de base, sin desviarse de su estrategia de guerra popular y prolongada, debían "dar batalla en todos los frentes y en todos los terrenos", yendo a "todos los centros de movilización para expulsar del movimiento a los traidores" (FAR, Comando Eva Perón, 1972). Es decir que, al igual que Montoneros, ya no rechazaban impulsar la movilización desde las estructuras del peronismo sino que buscaban hegemonizarlas, quitándoles base de sustentación a sus dirigentes. Con el correr de los meses esta política se expresó en la militancia barrial de miembros de las FAR en Unidades Básicas del movimiento, ya comentada. Al mismo tiempo, aunque más tardíamente que Montoneros, la organización sumó su apoyo a la campaña electoral del peronismo con vistas a los comicios del 11 de marzo de 1973.

El otro cambio sustantivo en las concepciones de las FAR fue su mayor predisposición a aceptar la existencia de contradicciones al interior de la burguesía nacional. Con ello, las FAR dejaban atrás un tópico central que había marcado el derrotero de sus grupos fundadores y la perspectiva de la organización durante sus primeros años. En la nueva coyuntura, la convergencia con sectores de la mediana burguesía se proclamaba viable al menos durante cierto tramo del proceso de liberación nacional y social. Paradójicamente o no, respecto de este punto, la postura de las FAR, no se encontraba tan distante de la del PC, partido en el que habían iniciado su militancia buena parte de sus fundadores.

Para finalizar, resta subrayar que, a través de todas las reorientaciones señaladas, las FAR buscaban consolidar la organización de modo de evitar el aislamiento, posicionarse como un actor con el cual la estrategia de Perón tuviera que contar y avanzar en la tarea de hegemonizar el movimiento. Su apoyo al candidato impulsado por el peronismo, Héctor José Cámpora, debe comprenderse bajo la misma lógica. La idea era 
convertir la campaña electoral en un "elemento concientizador" y que el período de funcionamiento de la "democracia liberal" sirviera para demostrar que este no era el camino para resolver los problemas fundamentales del pueblo. Como, también, para poner en evidencia el "carácter burgués y las limitaciones de la superestructura políticogremial del Movimiento" (FAR, 1972). En definitiva, para las FAR y para buena parte de Montoneros, la campaña y el futuro gobierno de Cámpora debían utilizarse como tácticas para consolidar las fuerzas propias en función de sus objetivos estratégicos: construir el Ejército del pueblo que condujera una guerra popular y prolongada en pos del socialismo (FAR y MONTONEROS, 1972).

Efectivamente, durante la campaña electoral ambas organizaciones adquirieron gran visibilidad, estrecharon filas y, tras la victoria de Cámpora, decidieron la fusión, determinando la composición de su nueva conducción nacional. Desde entonces se inició la unificación de sus estructuras internas y de las agrupaciones de activistas ligadas a cada una de ellas ${ }^{15}$. El "Acta de Unidad" fue firmada formalmente el 12 de octubre de 1973, nada menos que el día en que el viejo general asumió su tercera presidencia (FAR y MONTONEROS, 1973). Desde entonces, y en medio de su reacomodamiento interno, la nueva organización fusionada deberá asumir uno de sus mayores desafíos: encontrar el modo de posicionarse y determinar sus nuevas líneas de acción bajo un gobierno democrático, conducido nada menos que por Juan Domingo Perón.

\section{Palabras finales: un estilo de peronización marcado por las huellas de la} cultura de izquierdas

Si pensamos a las FAR en términos comparativos, podemos concluir que no fue la organización peronista que logró mayores nexos con el movimiento social más amplio (Montoneros) ni la que podía reivindicar una filiación más directa con la resistencia

\footnotetext{
${ }^{15}$ Para entonces, Montoneros era una organización mucho más numerosa que las FAR. Ya se había fusionado con Descamisados y había crecido exponencialmente gracias a sus ligazones con variadas agrupaciones de activistas, sobre todo con las Juventudes Peronistas. Lo cual, se evidenció en el nombre Montoneros para la nueva organización unificada, en el reparto de los cargos intermedios y en la composición de su conducción nacional. De acuerdo con Perdía (1997), ex dirigente montonero, esta última quedó integrada por 8 miembros, 5 de Montoneros y 3 de las FAR, al tiempo que los 2 primeros puestos de esa estructura correspondieron a la primera organización y Roberto Quieto ocupaba recién el tercer lugar.
} 
peronista del '55 (las FAP). En este sentido, creemos que un motivo central por el cual trascendieron fue el grado de elaboración teórica y la impronta marxista con que pensaron el peronismo. Lo cual, seguramente tenga que ver con la cantidad de intelectuales presentes en sus filas y, particularmente, con la figura de Carlos Olmedo, filósofo de formación y usualmente señalado como uno de los pensadores más importantes de la guerrilla argentina ${ }^{16}$. De allí que para cerrar este trabajo convenga subrayar los aspectos centrales de esa interpretación sobre el peronismo.

Como destacamos, en la apuesta por radicalizar el peronismo se consideraba central su conjugación con el marxismo, intento que por supuesto no era nuevo. La clave de dicha convergencia consistió en dos operaciones simultáneas. Por un lado, el marxismo fue considerado como herramienta de análisis de la realidad nacional y situado exclusivamente en el lugar de la teoría. Por su parte, el peronismo fue reivindicado como identidad política de los trabajadores, situándolo en el ámbito de la experiencia, allí donde se hallaban los elementos de la conciencia obrera que de ser radicalizados podían conducir al socialismo. En suma, según la expresión de un entrevistado, las apuesta de las FAR era actuar como "organización bisagra" entre marxismo y peronismo". Esta “posición bisagra” en la que buscaba instalarse explica que librara sus batallas en dos frentes simultáneamente: contra los sectores conciliadores del movimiento peronista y contra la izquierda marxista no peronista. O, parafraseando a Bourdieu (2008), que la apuesta de las FAR pueda verse como una lucha por incidir tanto en las disputas por la “visión legítima” del peronismo como por la "visión legítima” del marxismo. De allí que no resulte difícil comprender la energía dedicada en sus debates con el PRT-ERP, con quien compartía - y se disputaba - el mismo instrumento teórico.

Fue desde estos lentes teóricos marxistas que las FAR rescataron - construyeron el llamado "peronismo del pueblo", denominación con que expresaban su valoración de la experiencia forjada por los trabajadores en el marco del movimiento. Toda una política de construcción del peronismo si se quiere. De esta caracterización quisiera subrayar 2

\footnotetext{
${ }^{16}$ Además del propio Carlos Olmedo y del perfil universitario de buena parte de sus miembros, pueden mencionarse a Francisco Urondo, Juan Gelman y Juan Julio Roqué entre los intelectuales más destacados de la organización.

${ }^{17}$ Entrevista a "Militante de FAR 2".
} 
cuestiones: 1) la notable importancia atribuida a la experiencia para pensar la constitución de la clase obrera; y 2) en vinculación con lo anterior, la dimensión en que se sitúa la caracterización.

Se trata de un análisis que propone hallar la clave de interpretación del fenómeno peronista - cuya búsqueda, según Altamirano (2001a), signaba a las izquierdas desde 1955 - en una dimensión política y simbólica más que material o económica. En este sentido, podríamos poner fácilmente en diálogo ese análisis con la historia de los grandes debates sobre el peronismo en la Argentina, sobre todo con aquellas perspectivas preocupadas por comprender su persistencia como identidad política popular ${ }^{18}$. No casualmente, durante los años 1960, varios de estos intelectuales compartieron experiencias tanto académicas como políticas con los fundadores de las FAR.

Por último, y volviendo a los cauces de radicalización y a las huellas de origen, puede pensarse que estas concepciones de las FAR expresan algo así como un estilo de peronización particular, una forma de asumir la identidad peronista que lleva las marcas de estos orígenes de izquierda. Es decir, que muestran cierta sensibilidad propia de la cultura de izquierdas para pensar al peronismo. O, para plantearlo de otro modo, que hay allí una modalidad de respuesta típica al interrogante: ¿cómo se peronizan los militantes que provienen de la izquierda? Se trata de esta apuesta política por las virtualidades del peronismo, por sus potencialidades dada su composición de clases y la experiencia vivida por los trabajadores. Hay allí cierta expectativa que lleva la impronta del marxismo en el modo de pensar la conciencia obrera, esta conciencia "empírica" y "realmente existente" que puede devenir en conciencia verdadera o revolucionaria; una suerte de "estar ahí"

\footnotetext{
${ }^{18}$ Mínimamente, en este diálogo habría que considerar que para las FAR la adhesión de los trabajadores al peronismo constituía una opción claramente racional en términos de sus intereses de clase porque con ello satisfacían necesidades materiales largamente postergadas, tal como señalaron Murmis y Portantiero (1972) en su clásica polémica con Germani (1968). Con todo, este último autor había llamado la atención sobre una dimensión descuidada por aquellos y que será retomada desde distintas perspectivas por otros intelectuales. Entre ellos, Torre (1989), influido por los planteos de Touraine, o James (1999), por las premisas del marxismo británico para pensar la experiencia de la clase obrera peronista. Nos referimos a la dimensión política y cultural de aquellas adhesiones, lo cual permitía dar cuenta de la constitución - y sobre todo de la persistencia - de nuevas identidades colectivas populares. Se trata de la misma dimensión en que las FAR situaron su interpretación sobre el peronismo. En algunos puntos, su parentesco con el enfoque que James desarrollará años después resulta notable.
} 
por las potencialidades que eso encierra de convertirse en otra cosa. Se trata de una forma de ser y de estar en el peronismo que lleva las huellas de la cultura de izquierdas ${ }^{19}$.

La idea de un estilo de peronización característico de la FAR lleva inscripta la lógica de la pluralidad, invitando a indagar o sistematizar de modo comparativo las notas distintivas de estos otros estilos de peronización: ¿cómo se peronizan los militantes que provienen del cristianismo posconociliar?, ¿y los que vienen del nacionalismo? O la más clásica y estudiada: ¿cómo se izquierdiza el peronismo? Ahora bien, si tiene sentido indagar la impronta distintiva de esos diversos estilos de peronización es para aportar matices y complejidad a este magma resultante de las convergencias de distintas tradiciones político-culturales que fue la “nueva izquierda". En este sentido, cabe advertir que ese cauce de radicalización que le otorgó a las FAR su perfil particular no impidió que sus planteos convergieran con los de organizaciones provenientes de orígenes disímiles, y que resultaran atrayentes para militantes formados en otras tradiciones políticoculturales. De hecho, las transformaciones que todas estas tradiciones experimentaron en el período, y los puentes que posibilitaron, constituyen una de las claves de la envergadura de la "nueva izquierda". En el caso de las FAR, desde sus inicios lograron sumar a militantes formados en el catolicismo postconciliar, influidos por el diálogo entre "cristianos y marxistas" y que para entonces ya habían pasado de la "opción por los pobres" a la "opción por el peronismo" (el grupo de Tucumán). Al mismo tiempo, desde 1971, cuando las FAR se identificaron públicamente como peronistas, se abrió una nueva dinámica política para la organización. Desde entonces, no sólo se incorporaron activistas de izquierda que emprendían el mismo camino de peronización que los fundadores de las FAR. También lo hicieron militantes de trayectoria peronista atraídos por el discurso de una organización que reivindicaba su misma identidad política desde una visión de izquierda y apelando a un lenguaje decididamente marxista. Es decir, activistas cuyas trayectorias expresaban la dinámica inversa: la progresiva redefinición del peronismo que se venía operando entre las propias filas del movimiento. Tras los intentos de convergencia entre las OAP, la última expresión de este proceso fue la fusión de las FAR con Montoneros.

\footnotetext{
${ }^{19}$ En el mismo sentido, aunque para otro contexto y vertientes peronistas, puede verse Altamirano (2001b).
} 


\section{Referencias}

ALTAMIRANO, Carlos. Peronismo y cultura de izquierda en la Argentina (1955-1965). En: ALTAMIRANO, Carlos. Peronismo y cultura de izquierda. Buenos Aires: Temas, 2001a, p. 49-79.

ALTAMIRANO, Carlos. El peronismo verdadero. En: ALTAMIRANO, Carlos. Peronismo y cultura de izquierda. Buenos Aires: Temas, 2001b, p. 107-114.

DEBRAY, Régis. Revolución en la Revolución. La Habana: Casa de las Américas, 1967.

EJERCITO REVOLUCIONARIO DEL PUEBLO (ERP). Crítica del ERP al Reportaje a las FAR. [1971]. Militancia, n.4, p. 35-38, julio 1973.

BOURDIEU, Pierre. Describir y prescribir: las condiciones de posibilidad y los límites de la eficacia política”. En: BOURDIEU, Pierre. ¿Qué significa hablar? Madrid: Akal, 2008, p. 123138.

DONATELLO, Luis Miguel. Catolicismo y montoneros: religión, política y desencanto. Buenos Aires: Manantial, 2010.

DONATELLO, Luis Miguel; CATOGGIO, María Soledad. Sociabilidades católicas y carreras militantes. En: BUFANO, Sergio; LOTERSZTAIN, Israel (Eds.). Anuario Lucha Armada en la Argentina. Buenos Aires: Ejercitar la Memoria Editores, 2010, p. 148- 155.

FRONDIZI, Silvio. Bases y puntos de partida para una solución popular. Buenos Aires: Ciencias Políticas, 1961.

FUERZAS ARMADAS REVOLUCIONARIAS (FAR). Objetivos y métodos de nuestra producción operacional [1970]. Legajo n. 641, Carpeta Bélico, Mesa DS, Archivo DIPPBA, Comisión Provincial por la Memoria.

FUERZAS ARMADAS PERONISTAS (FAP). Documento Político Número 1 [1971]. En: DUHALDE, Eduardo; PÉREZ, Eduardo (Comps.). De Taco Ralo a la alternativa independiente: historia documental de las Fuerzas Armadas Peronistas y del Peronismo de Base. Tomo I. Buenos Aires: De la Campana, 2003, p. 189-200.

FUERZAS ARMADAS REVOLUCIONARIAS (FAR) [Regional Córdoba] ([1971]). El combate de Fiat. Legajo n. 641, Carpeta Bélico, Mesa DS, Archivo DIPPBA, Comisión Provincial por la Memoria.

FUERZAS ARMADAS REVOLUCIONARIAS (FAR). Con el fusil del Che. En: S/datos (comp.). 
América Latina en Armas. Buenos Aires: M.A, 1971a, p. 107-114.

FUERZAS ARMADAS REVOLUCIONARIAS (FAR). Los de Garín. Cristianismo y revolución, n.28, p. 56-70, abril 1971b.

FUERZAS ARMADAS REVOLUCIONARIAS (FAR). 13 preguntas a las FAR. Nuevo Hombre, n.17, p. 2-5, noviembre 1971c.

FUERZAS ARMADAS REVOLUCIONARIAS (FAR). Documento de actualización política (1972). Legajo n. 641, Carpeta Bélico, Mesa DS, Archivo DIPPBA, Comisión Provincial por la Memoria.

FUERZAS ARMADAS REVOLUCIONARIAS (FAR). Nuestra respuesta elaborada por el compañero Olmedo [1971]. Militancia, n.4, p. 38-49, julio 1973.

FUERZAS ARMADAS REVOLUCIONARIAS (FAR), Comando Eva Perón (1972). A nuestro Pueblo. Dock Sur, 30 de abril de 1972. Legajo n. 641, Carpeta Bélico, Mesa DS, Archivo DIPPBA, Comisión Provincial por la Memoria.

FUERZAS ARMADAS REVOLUCIONARIAS (FAR) y MONTONEROS. Opiniones sobre los problemas centrales de la guerra revolucionaria en esta etapa. En: FAR. Boletín, n. 4, 1972, s/datos.

FUERZAS ARMADAS REVOLUCIONARIAS (FAR) y MONTONEROS. Acta de la unidad. Militancia, n. 19, p. 26-27, 1973.

GERMANI, Gino. Política y sociedad en una época en transición. Buenos Aires: Paidós, 1968.

GILLESPI, Richard. Soldados de Perón: los montoneros. Buenos Aires: Grijalbo, 1998.

GONZÁLEZ CANOSA, Mora. Los pasos perdidos. Acerca del itinerario político-ideológico de uno de los grupos fundadores de las FAR (1960-1966). Cuestiones de Sociología, La Plata, n.7, p. 299-326, primavera 2011.

GONZÁLEZ CANOSA, Mora. Modelo para armar. Itinerarios y ámbitos disidentes del Partido Comunista en la formación de uno de los grupos fundadores de las FAR (19601967). Izquierdas: una mirada histórica desde América Latina, Santiago de Chile, n.12, p. 111-142, abril 2012.

GONZÁLEZ CANOSA, Mora. Las Fuerzas Armadas Revolucionarias. Orígenes y desarrollo de una particular conjunción entre marxismo, peronismo y lucha armada (1960-1973). 2013, Tesis (Doctorado en Ciencias Sociales) - Universidad de La Plata, La Plata, $2013 a$. 
GONZÁLEZ CANOSA, Mora. Un sendero guevarista: pervivencias y torsiones en los orígenes de las Fuerzas Armadas Revolucionarias. Izquierdas: una mirada histórica desde América Latina, Santiago de Chile, n.15, p. 56-83, abril 2013b.

GONZÁLEZ CANOSA, Mora. Políticas de construcción del peronismo. El discurso de las FAR en los albores de la década del setenta en Argentina. Tempo e Argumento, Florianópolis, v. 7, n. 14, p. 179 - 215, jan./abr., 2015.

GONZÁLEZ CANOSA, Mora. La política armada. La lógica de las prácticas políticas de las FAR y el problema de la relación con las masas durante los primeros años de la organización. En: PITTALUGA, Roberto (Comp.). Formas de la política: experiencias de activismo en el pasado reciente. Argentina (1969-2010). La Pampa: EdUNLPalm, 2016.

JAMES, Daniel. Resistencia e integración. Buenos Aires: Sudamericana, 1999.

LANUSSE, Lucas. Montoneros. El mito de sus doce fundadores. Buenos Aires: Vergara, 2005.

LA ROSA Blindada, n. 1, 9, p. 1964-1966.

LEWINGER, Arturo et al. Del peronismo al Tercer Movimiento Histórico. Buenos Aires: $3 \mathrm{MH}, 1964$.

LEWINGER, Jorge Omar; PIRIZ, Luis y DIAMANT, Jorge. De la Reforma Universitaria a la Revolución Nacional. Buenos Aires: Nueva Generación. 1966.

LUVECCE, Cecilia. Las FAP y el peronismo de base. Buenos Aires: CEAL, 1993.

MOVIMIENTO. POR UN MOVIMIENTO POPULAR REVOLUCIONARIO (periódico), n. 1 al 4, junio-diciembre de 1961.

MONTONEROS. Memoria del año 1971. En: BASCHETTI, Roberto. De la guerrilla peronista al gobierno popular. Documentos 1970-1973. Buenos Aires: De la Campana, 1997, p. 363376.

MURMIS, Miguel; PORTANTIERO, Juan Carlos. Estudios sobre los orígenes del peronismo. Buenos Aires: SXXI, 1972.

[OLMEDO, Carlos]. Notas para una valoración de la situación nacional [1968]. Legajo $\mathbf{n}$. 320, Carpeta Bélico, Mesa DS, Archivo DIPBA, Comisión Provincial por la Memoria. 
[OLMEDO, Carlos]. Informe de la Reunión Nacional de Mandos [1970]. Legajo n. 320, Carpeta Bélico, Mesa DS, Archivo DIPPBA, Comisión Provincial por la Memoria.

PARTIDO COMUNISTA. Nuestra Palabra (periódico), años 1963-1966.

PERDÍA, Roberto. La otra historia: testimonio de un jefe montonero. Buenos Aires: Ágora, 1997.

PÉREZ, Eduardo. Una aproximación a la historia de las Fuerzas Armadas Peronistas. En: DUHALDE, Eduardo; PÉREZ, Eduardo (Comps.). De Taco Ralo a la alternativa independiente:historia documental de las Fuerzas Armadas Peronistas y del Peronismo de Base. Tomo I. Buenos Aires: De la Campana, 2003, p. 9-32.

RAIMUNDO, Marcelo. Izquierda peronista, clase obrera y violencia armada: una experiencia alternativa. Sociohistórica, n. 15-16, p. 99-128, 1er y 2 do semestre 2004.

SALAS, Ernesto; CASTRO, Flora. Norberto Habegger. Cristiano, descamisado, montonero. Buenos Aires: Colihue, 2011.

TORRE, Juan Carlos. Interpretando (una vez más) los orígenes del peronismo. Desarrollo Económico, v. 27, n.112, p. 525-548, feb./mar., 1989.

TORRE, Juan Carlos. Escribir historia política, escribir historia. Entrevista a Juan Carlos Torre realizada por Elisa Pastoriza. PolHis, n. 8, p. 241-245, 2011.

TORTTI, Cristina. Protesta social y Nueva Izquierda durante el Gran Acuerdo Nacional. En: PUCCIARELLI, Alfredo (Ed.). La primacía de la política, Buenos Aires: Eudeba, 1999, p. 205230.

TORTTI, Cristina. La nueva izquierda argentina. La cuestión del peronismo y el tema de la revolución. En: TORTTI, Cristina (Dir.); CHAMA, Mauricio; CELENTANO, Adrián (Eds.). La "nueva izquierda argentina": socialismo, peronismo y revolución. Rosario: Prohistoria, 2014, p. 15-33.

VANGUARDIA REVOLUCIONARIA. Los comicios del 7 de julio y las perspectivas de la izquierda. Buenos Aires: VR, 1963.

VANGUARDIA REVOLUCIONARIA. Revista Táctica, n. 1, 1964.

VANGUARDIA REVOLUCIONARIA. Vanguardia Revolucionaria (periódico), n. 1 y 2, 1964. 
